\title{
FIRM-SPECIFIC FACTORS AND THE MARKET REACTION TO DIVIDEND CHANGE ANNOUNCEMENTS: EVIDENCE FROM EUROPE
}

\section{Elisabete S. VIEIRA*}

\section{Abstract}

According the dividend signalling hypothesis, it is expected a positive relationship between dividend change announcements and the subsequent share price reactions. However, empirical results are not consensual. This study investigates whether firm-specific factors contribute to explain a negative market reaction to dividend change announcements, contributing to the scarce analysis of firm-specific factors explaining the inverse share price reaction to dividend change announcements. The study applies the panel data approach to three European markets. The results show that the market reaction to dividend change announcements is negatively associated with the firm size. We find that the negative market reaction to dividend increase announcements is associated with firms that have, on average, lower dividend changes and higher growth opportunities. Moreover, the results suggest that a high percentage of dividend negative changes, decreases the likelihood that the market reacts positively to a dividend decrease announcement. Globally, we find some evidence for the dividend signalling hypothesis.

Key Words: Cash Dividends, Signalling Hypothesis, Firm-Specific Factors

\section{$\ddot{O} z e t$}

Temettü sinyalizasyon hipotezi göre, temettü değişiklik duyuruları ve sonraki hisse fiyatı reaksiyonlar arasında pozitif bir ilişki beklenmektedir. Ancak, ampirik sonuçlar arasında fikir birliği yoktur. Bu çalışma, temettü

\footnotetext{
"Assoc. Prof., GOVCOPP Unit Research, ISCA Department, University of Aveiro, Campus Universitário de Santiago, e-mail: elisabete.vieira@ua.pt
} 
değişikliği duyurularına ters hisse fiyatı reaksiyonunu açıklayan firmaya özgü faktörlerin kıt analizine katkıda bulunarak, firmaya özgü faktörlerin, temettü değişikliği duyurularına olumsuz pazar reaksiyonunu açıklamaya katkısı olup olmadığını incelemektedir. Çalışmada üç Avrupa pazarları için panel veri yaklaşımı geçerlidir. Sonuçlar, temettü değişikliği duyurularına pazar reaksiyonunun firma büyüklüğ̈̈ ile negatif ilişkili olduğunu göstermektedir. Temettü artışı duyurularına olumsuz piyasa reaksiyonunun ortalama olarak daha düşük temettü değişikliği ve daha yüksek büyüme firsatı olan firmalarla bağlantılı olduğu tespit edilmiştir. Ayrıca sonuçlar, olumsuz temettü değişikliklerinin büyük kısmının piyasanın temettü azalış duyurusuna olumlu tepki veriş olasılığını azalttığını öne sürmektedir. Sonuç olarak, temettü sinyalizasyon hipotezi için bazı kanıtlar bulunmuştur.

Anahtar Kelimeler: Nakit Temettü, Hipotez, Firma Özgü Faktörler Sinyalizasyon

\section{Introduction}

Because of the information asymmetry between management and investors, managers use dividends to signal the managers' expectations about future cash flows of firms (Bhattacharya, 1979; John and Williams, 1985 and Miller and Rock, 1985). Consequently, and according the dividend signalling hypothesis, it is expected that dividend change announcements and share price reactions are positively related.

A vast number of empirical studies found evidence supporting the dividend signalling hypothesis, such as Pettit (1972, 1976), Aharony and Swary (1980), Asquith and Mullins (1983), Dhillon and Johnson (1994), Lee and Ryan (2000, 2002), Hussin et al. (2010), Yilmaz and Selcuk (2010) and Jiang and Stark (2011), among others. However, some authors found no evidence of a significant market reaction to dividend change announcements, suggesting that dividend announcements does not convey valuable information to the market, contrary to the content information dividend hypothesis (Lang and Litzenberger, 1989; Benartzi et al., 1997; Conroy et al., 2000; Chen et al., 2002; Abeyratna and Power, 2002; Fu and Morgan, 2008; Ali and Chowdhury, 2010 and Asamoah, 2010).

Furthermore, several studies found evidence of a significant percentage of cases where share price reactions are opposite to the dividend changes direction (Asquith and Mullins, 1983; Benesh et al., 1984; Born et al., 1988; 
Dhillon and Johnson, 1994; Healy et al., 1997; Fu and Morgan, 2008 and Urooj and Zafar, 2008).

Several authors have documented a relationship between market share price reaction to dividend change announcements and firm-specific factors (Asquith and Mullins, 1983; Ghosh and Woolridge, 1988; Eddy and Seifert, 1988; Haw and Kim, 1991; Mitra and Owers, 1995; Healy et al., 1997 and Malkawi, 2008).

In this context, we will analyze whether firm-specific factors can influence the market reaction in the dividend announcement period, relating the firm specific factors to the market share price reaction around the dividend change announcements date.

Our study contributes to the existing literature in several ways. First, we examine events with an inverse market reaction to dividend change announcements. Second, we test whether firm-specific factors contribute to explain a negative market reaction to dividend change announcements, contributing to the scarce analysis of firm-specific factors explaining the inverse share price reaction to dividend change announcements. Third, we analyze different European markets: the UK, the French and the Portuguese markets. While the UK market is a country of Anglo-Saxon influence, the other two are characterised by a continental influence. The French and the Portuguese markets are less intensively researched, so, they are in need of research. As the best of our knowledge, this is the first study to analyze the contribution of firm specific factors in explaining the phenomenon of the inverse market reaction to dividend change announcements from a dataset of European countries.

Our evidence suggests that the market reaction to dividend change announcements is negatively associated with the firm size. Globally, we find some evidence for the dividend signalling hypothesis. Moreover, the results show that firms with a negative market reaction to dividend increase announcements have, on average, lower dividend changes and higher growth opportunities. Thus, we can say that for high growth opportunities firms, the market interprets a dividend increase as a negative signal.

The remainder of this paper is organised as follows. Section 2 presents the literature review and formulates the hypotheses. The methodology and 
the sample selection are described in Section 3. Section 4 presents and discusses the empirical results. Finally, section 5 concludes.

\section{Literature Review and Hypotheses}

Asquith and Mullins (1983) found that market reaction to dividend announcements depends on the magnitude of the dividend payment. Ghosh and Woolridge (1988) concluded that the most significant firm specific factors that influence this relationship are the percentage change in dividend, the firms' size, the share performance before the announcement date and the negative information released before the dividend change.

Eddy and Seifert (1988), Haw and Kim (1991) and Mitra and Owers (1995) found a negative relation between firm size and abnormal returns. Healy et al. (1997) results suggested that firms whose capital market have reacted negatively to an initial dividend announcement documents lower dividend yield ratio and PER than firms whose reaction was positive and higher debt/equity ratio, current ratio and growth earnings before the announcement period.

Malkawi (2008) find that factors such as size, profitability and age increase the probability to pay dividends whereas financial leverage decreases the likelihood to pay dividends.

More recently, Ahmad and Javid (2009) find a positive relationship between the dividend payout and profitability, past earnings and cash flows and a negative relation between the dividend payout and firm size, leverage and market capitalization.

Based on the previous literature, we try to identify the firm-specific variables that influence the market reaction to dividend announcements, which we believe are effective proxies to measure the information content of dividend change announcements. Consequently, we consider the following factors: firm size, dividend changes, earnings growth, market to book ratio, price/earnings ratio and the debt/equity ratio, which are explained below.

Firm Size (FS) - To the extent that informational asymmetry is greater for small firms than for large firms (Haw and Kim, 1991), the information content of dividend announcements will be greater for small firms. Therefore, we expect this coefficient to have a negative signal. We use 
market capitalization as a surrogate for firm size. FS is defined as the natural $\log$ of the market value of common equity at the end of the year before the dividend change year. We do not use the common equity market value because of firms' different capital structure. In this context, we formulate the following hypothesis:

H1: "The market reaction to dividend change announcements is negatively associated with firm size"

Percentage Change in Dividends (PCD) - We consider the percentage change of dividends as a proxy for the information content of dividends (Asquith and Mullins, 1983). PCD is defined as the change in dividends divided by the share price in the announcement day. We consider the absolute term of this variable to overcome the problem of interpreting the coefficient signal depending on the direction of dividend changes. Assuming that a bigger change reveals more information, the coefficient of this variable is expected to be positive. The correspondent hypothesis is:

H2: "The market reaction to dividend change announcements is positively associated with the percentage change of dividends"

Earnings Growth (EG) - Past earnings is a determinant of dividend policy (Lintner, 1956). We analyse prior earnings o test whether their growth magnitude is a predictor of the market reaction to dividend change announcements. EG is computed as the average earnings growth rate based on the year prior to the dividend change year ${ }^{1}$, considering the absolute term of this variable. We expect a positive relation between earnings growth and the market reaction to dividend change announcements. Thus, we consider the subsequent hypothesis:

H3: "The market reaction to dividend change announcements is positively associated with earnings growth"

Market to Book Ratio (MB) - We consider the MB ratio as a proxy for firm maturity and growth opportunities. According the signalling hypothesis, the coefficient on MB ratio must be positive, since a high ratio value means that a firm has strong growth prospects, which can be seen as a

${ }^{1}$ We will take special care when calculating percentage changes involving a negative value of earnings to ensure that any change in sign did not give a false picture of any deterioration or improvement in earnings. 
good new. However, in the perspective of the maturity hypothesis, firms with fewer investment opportunities will have more free cash flows to pay dividends, so, the signal is expected to be negative. $\mathrm{MB}$ is calculated by dividing the market price per share at the dividend change announcement date by the book value per share at the end of the year before the dividend change year. The fourth hypothesis is formulated as follows:

H4: "The market reaction to dividend change announcements is positively associated with the market to book ratio"

Price/Earnings Ratio (PER) - A high PER may mean that investors believe the firm has growth opportunities and/or its earnings and cash flows are relatively safe. For firms that increase their dividends, it may also signal that they have less growth prospects than expected. Therefore, we cannot determine, a priori, the predicted signal for this variable. PER is computed as the price per share divided by the earnings per share. The next hypothesis is:

H5: "The market reaction to dividend change announcements is significantly associated with the PER ratio"

Debt/Equity Ratio (DE) - The proxy we choose for firms' financial risk is the debt to equity ratio. Assuming the reluctance of managers to decrease dividends (Lintner, 1956), the higher the financial risk, the lower the probability that a firm increase dividends if managers are unsure about their capacity to continue paying dividends. Therefore, we expect this coefficient to have a positive signal. DE is computed as the book value of total debt divided by the total book value of equity at the end of the year prior to the dividend change announcement. Consequently, we formulate the last hypothesis:

H6: "The market reaction to dividend change announcements is positively associated with the debt to equity ratio"

If we find firm-specific variables significantly associated with price changes in the dividend announcement period, we will find evidence of firm-specific factors influencing the market reaction to dividend announcements, and, potentially, find some reasons for a negative relationship between dividends and share price movements in the announcement period. 


\section{Sample Selection and Methodology}

In this section we begin by presenting the sample selection. Next, we specify the methodology we will use in order to test the formulated hypotheses.

\subsection{Sample Selection}

We choose to examine the UK, the French and the Portuguese markets. Although they are all European markets, they are different from each other for several reasons. Firstly, while the UK is one of the most important European capital markets, the French and the Portuguese markets are smaller, particularly the last one. Secondly, Portugal and France firms are characterized by higher ownership concentration than the UK firms. Thirdly, Portugal and France present financial model banking based system, and the UK market is a market-based country, like the US. Finally, whereas UK is a country of Anglo-Saxon influence, the other two countries are characterised by a continental influence.

The sample is drawn from dividend announcements of non-financial firms listed on the Euronext Lisbon and Paris, both integrated on the NYSE Euronext, and London Stock Exchange, for the period between 2003 and 2010. We use the Bloomberg database for the announcement dates and the Datastream database for all the other needed information.

In order to obtain the final sample, we consider the following criteria: The firm is listed on the respective stock exchange the year before the dividend events; The firm's financial data is available on the Datastream database at the year before the dividend events; The firm paid an annual ordinary dividend in the current and previous year; For the Portuguese and French firms, the dividend, earnings or other potentially contaminating announcements did not occur within 5 trading days of each other. For the UK market, dividends and earnings are usually announced in the same date. We, therefore, exclude the dividend events for which dividends and earnings information were announced on separate dates. We have adapted the methodology in order to separate the two effects (dividends and earnings).

Our unbalanced panel sample events include dividend increases, no changes and decreases from 2004 to 2010. The final sample contains 4,442 events: 
2,927 increases, 686 decreases and 829 dividend no change events, which corresponds, respectively, to $66 \%, 15 \%$ and $19 \%$ of the sample.

\subsection{Methodology}

To measure the market reaction to dividend change announcements, we consider the "buy-and-hold" abnormal return (BHAR) for share i from time a to $b$, which takes the following form:

$$
B H A R_{i(a \text { to } b)}=\prod_{t=a}^{b}\left(1+R_{i, t}\right)-\prod_{t=a}^{b}\left(1+R_{m, t}\right)[1]
$$

where $\mathrm{Ri}, \mathrm{t}$ is the return of stock $\mathrm{i}$ in day $\mathrm{t}$, and $\mathrm{Rm}, \mathrm{t}$ is the return of the respective market on date $t$. The time period a to $b$ constitutes three trading days from $\mathrm{t}=-1,0,+1$, with 0 being the event date.

Following Ghosh and Woolridge (1988), we estimate the following regression:

$\left|B H A R_{i, 1 \text { to }+1}\right|=\alpha+\beta_{1} F S_{i}+\beta_{2}\left|P C D_{i}\right|+\beta_{3}\left|E G_{i}\right|+\beta_{4} M B_{i}+\beta_{5} P E R_{i}+\beta_{6} D E_{i}+\theta c+\varepsilon_{i, t} \quad$ [ 2]

where:

$\mathrm{FS}_{\mathrm{i}}=$ firm size for share $\mathrm{i}$, computed as the natural $\log$ of the market value of common equity at the end of the year before the dividend change year;

$\mathrm{PCD}_{\mathrm{i}}=$ percentage change of dividends for share $\mathrm{i}$, computed as the annual change in dividends divided by the share price in the announcement day;

$\mathrm{EG}_{\mathrm{i}}=$ earnings growth rate for share $\mathrm{i}$, computed as the average earnings growth rate based on the year prior to the dividend change year;

$\mathrm{MB}_{\mathrm{i}}=$ market to book ratio for share $\mathrm{i}$, calculated by dividing the market price per share at the dividend change announcement date by the book value per 
share at the end of the year before the dividend change year;

$\mathrm{PER}_{\mathrm{i}}=$ price earnings ratio for share $\mathrm{i}$, computed as the price per share at the announcement date divided by the earnings per share at the end of the year before the dividend change year;

$\mathrm{DE}_{\mathrm{i}}=$ debt/equity ratio for share $\mathrm{i}$, calculated as the book value of total debt divided by the total book value of equity at the end of the year prior to the dividend change announcement;

$\theta_{\mathrm{c}}=$ Country dummy variables standing for country specific effect;

$\varepsilon_{\mathrm{i}, \mathrm{t}}=$ White-noise error.

To overcome the problem of interpreting the coefficient signal depending on the direction of dividend changes, and consistent with Haw and Kim (1991), we consider the absolute term of such variables. All financial variables are measured at the end of the firm's fiscal year immediately prior to the dividend announcement.

Employing the panel data methodology, we use the pooled ordinary least squares (OLS), the fixed effects model (FEM), and the random effects model (REM). Subsequently, we use the F-statistic and the Hausman (1978) test to choose the most appropriate model. We present the standard errors corrected for heteroscedasticity and covariance, based on the White's (1980) heteroscedasticity consistent standard errors method.

To see if the proxies are highly correlated and, in effect, proxying for one another, we analyze the correlation between the independent variables.

Next, we run a logistic regression to analyze the relation between the probability of a negative market reaction to dividend increase announcements and the firm-specific characteristics, as well as to analyze 
the relation between the probability of a positive market reaction to dividend decrease announcements and the firm-specific characteristics.

For the dividend increase events, we express the regression as: $B H A R,_{1 \text { to }+1}=\alpha+\beta_{1} F S_{i}+\beta_{2} L P C D_{1}+\beta_{3} L E G+\beta_{4} L M B+\beta_{5} L P E R_{t}+\beta_{6} L D E_{1}+\theta c+\varepsilon_{t}$

where:

$$
\begin{array}{ll}
\text { BHARI }_{\mathrm{i},-1 \text { to }+1}= & \begin{array}{l}
\text { dummy variable that takes value } 1 \text { if } \mathrm{BHAR}_{\mathrm{i},-} \\
\text { ito+1 }
\end{array} \\
\mathrm{LPCD} & =\text { negative and } 0 \text { otherwise; }
\end{array}
$$

For the dividend decrease events, we express the regression in the following manner:

$$
B H A R D_{l,-1 \mathrm{to}+1}=a \dashv \beta_{1} F S_{i} \dashv \beta_{2} \mathrm{LPCD}_{1} \dashv \beta_{3} \mathrm{LEG}_{\mathrm{i}} \dashv \beta_{4} L M B_{i} \dashv \beta_{5} L P E R_{i} \dashv \beta_{6} L D E_{i} \dashv \varepsilon_{t}[\mathrm{3b}]
$$

where $\mathrm{BHARD}_{\mathrm{i},-1 \text { to }+1}$ is a dummy variable that takes value 1 if $\mathrm{BHAR}_{\mathrm{i},-1 \text { to+1 }}$ is positive and 0 otherwise.

Afterwards, we look at the contribution of the firm specific variables in explaining the market reaction to dividend change announcements, identifying the different types of events and looking separately at dividend increase and dividend decrease announcements. Because the UK firms usually announce both dividends and earnings simultaneously, we divide the sample in the following events: dividend increase-earnings increase (DIEI), dividend increase-earnings decrease (DIED) dividend decrease-earnings increase (DDEI), dividend decrease-earnings decrease (DDED) and dividend no-changes (DNC). 
Consequently, the regression can be expressed in the following manner:

$$
\begin{array}{r}
\left|B H A R_{i, 1 \text { to }+1}\right|=\alpha+\beta_{1} \Phi \times F S_{i}+\beta_{2} \Phi \times\left|P C D_{i}\right|+\beta_{3} \Phi \times\left|E G_{i}\right|+ \\
+\beta_{4} \Phi \times M B_{i}+\beta_{5} \Phi \times P E R_{i}+\beta_{6} \Phi \times D E_{i}+\theta c+\varepsilon_{i, t}
\end{array}
$$

where $\Phi$ is the vector of coefficients for the dummy variables relating the dividend and earnings changes, set equal to 1 respectively, if (a) both dividend and earnings increases; (b) dividend increases and earnings decreases; (c) dividend decreases and earnings increases; (d) both dividend and earnings decreases, and 0 otherwise.

Finally, we will analyze the firm characteristics according to the market reaction to dividend change announcements. Specifically, we wish to study whether specific factors can be distinguished between the events with a positive reaction to dividend increases (PRDI) and a negative reaction to dividend increases (NRDI), and between the events with a negative reaction to dividend decreases (NRDD) and a positive reaction to dividend decreases (PRDD), since the events in the situations PRDI and NRDD are consistent with the dividend information content hypothesis, whereas events characterized by situations NRDI and PRDD are paradoxical cases.

\section{Empirical Results}

The Relation between Abnormal Return and Firm-specific variables

To evaluate whether firm-specific factors affect the market reaction in the dividend announcement period, we start by testing the relationship between the $\mathrm{BHAR}_{-1 \text { to }+1}$ and the firm-specific variables, estimating regression [ 2], which results are shown in Table 1.

We start by estimating the Pearson correlations among the independent variables. Panel A presents the correlation matrix among the exogenous variables along with the statistical significance. The higher correlation coefficient is between the $\mathrm{DE}$ and the $\mathrm{MB}$ ratio, exhibiting a value of $34.4 \%$. We are expecting high values for the correlation between MB ratio and PER. Although the coefficient is one of the highest, it only exhibits a value of about $6 \%$. Consequently, we can conclude that these two variables are not proxying for one another. Because all the correlation coefficients are below $50 \%$, it does not appear to be sufficiently large to cause concern about multicollinearity problems. 
The results of the best model for regression [ 2], chosen according to the $\mathrm{F}$ statistic and the Hausman test, are shown in Panel B. ${ }^{2}$

The only independent variable that contributes in explaining the market return is the FS, with the expected signal. We find evidence that the market reaction to dividend change announcements is negatively associated with the firm size, giving evidence for the hypothesis H1. This result is in line with prior studies, such as Ghosh and Woolridge (1988), Haw and Kim (1991) and Mitra and Owers (1995).

Influence of Firm-Specific Factors on the Probability of Inverse Market Reaction to Dividend Announcements

Table 2 presents the results of the logistic regression [ 3] for dividend increase events (Panel A) and for dividend decrease events (Panel B), in order to analyze the relation between the probability of a negative (positive) market reaction to dividend increase (decrease) announcements and the firm-specific characteristics.

In what concerns the dividend increases, the results show that two out of the six variables are statistically significant. The LPCD is negative and the $\mathrm{LMB}$ is positive.

LPCD is negative and statistically significant, suggesting that a high percentage of dividend changes decreases the likelihood that the market reacts negatively to a dividend increase announcement. This evidence suggests that dividend increases with high amplitude convey good news to the market, which is consistent with the dividend signalling hypothesis (Dhillon and Johnson, 1994; Lee and Ryan, 2000, 2002; Hussin et al., 2010; Jiang and Stark, 2011, among others). Furthermore, it is an indication that the magnitude of the dividend is directly associated with the signal dimension transmitted to the market (e.g. Asquith and Mullins, 1983).

The LMB ratio is positive, suggesting that the market has a higher probability to react negatively to dividend increases if firms have growth opportunities. This seems to be in accordance with the free cash flow hypothesis (Jensen, 1986).

${ }^{2}$ To simplify, we do not report the other models, but they are available from authors upon request. 
Panel B presents the regression results of the relation between the probability of a positive market reaction to dividend decrease announcements and firm specific characteristics. Once more, the significant coefficients are LPCD and LMB, both of them with a negative signal.

The negative value for LPCD indicates that a high percentage of dividend negative changes decrease the likelihood that the market reacts positively to a dividend decrease announcement. This evidence suggests that dividend decreases with high amplitude convey bad news to the market, which, once more, is in accordance with the assumptions of the dividend signalling hypothesis.

In what concerns the LMB, the negative coefficient shows that the market has a lower probability to react positively to dividend decreases if firms have growth opportunities, which seems somewhat contradictory to the results found in Panel A, in respect to dividend increases. It might be an indication that the market reacts strongly to dividend decreases than to dividend increases, suggesting some asymmetry in the market reaction to dividend increases or decreases (e.g. Amihud and Li, 2002).

The Influence of Firm-Specific Variables conditional on the direction of Dividend Announcements

The best model estimation results obtained when we run the regression [ 4] to determine the contribution of the firm specific variables in explaining the market reaction to dividend change announcements are reported in Table 3.

The results show that the FS coefficients are statistically significant, and with the expected signal, finding evidence that the market reaction to dividend change announcements is negatively associated with the firm size. These results are in accordance with the ones presented in Panel B of Table 1 , giving evidence for the hypothesis that the market reaction to dividend change announcements is negatively associated with firm size $\left(\mathrm{H}_{1}\right)$.

We find significant values for the PER coefficients, in what concerns the dividend decrease events. However, it has a different signal for earnings increases and earnings decreases. This might be an indication that earnings announcements convey information beyond what is revealed by dividend change announcements, which is in agreement with the results of previous 
studies, such as the ones of DeAngelo et al. (1992) and Abeyratna and Power (2002).

\section{Direction of Dividend Announcements and Firm-Specific Variables}

Finally, we analyze the differences in firm characteristics between the distinct market reaction (positive or negative) to dividend increase and dividend decrease announcements in order to see if there are any systematic differences between events with a positive and a negative market reaction for each of the two types of events.

Table 4 presents the mean values for the selected specific factors and the t-statistic test for the differences between the means of the two groups (PRDI versus NRDI and NRDD versus PRDD events).

For the dividend increase events, we find no evidence of statistically significant differences of mean between dividend increases with a positive and a negative market reaction.

In what concerns the dividend decrease events, the PER ratio tend to be lower for the events with a positive market reaction to dividend decreases. These results suggest that investors understand the dividend decrease decision by firms that have lower growth prospects, not punishing so much their decision.

\section{Robustness Checks}

To evaluate the robustness of the results, we repeat the analysis using different ways to calculate some of the variables, as well as considering alternative explanatory variables, reflecting other firm-specific factors.

We start by considering different ways to calculate some of the variables. We substitute the market value of common equity at the end of the year before the dividend change year, for the total of assets, in the case of the FS variable. Globally, the results are quite similar, so our conclusions are not changed. Secondly, we include an additional liquidity variable that measures the adequacy of a firm's cash resources to meet its near-term cash obligations, the working capital ratio (WCR), computed as total current assets divided by total current liabilities at the end of year before the announcement period. The regression results show that WCR does not contribute in explaining the market reaction to dividend change 
announcements. Finally, we include the $\mathrm{KZ}$ index, as it was denominated by Lamont et al. (2001), to proxy for financial constraints. The index constructed by these authors uses the coefficients of the regression of Kaplan and Zingales (1997) work $^{3}$. Once more, this variable does not explain the market reaction surrounding dividend change announcements.

Given these results, our main conclusions maintain the same.

\section{Conclusions}

This paper tries to identify firm-specific factors that contribute to explain the market reaction to dividend change announcements, using data from three different European countries.

We must be aware of some limitations of our study, such as the lack of information about dividend analysts' forecasts in order to determine dividend surprises ${ }^{4}$.

The results show that the firm specific variable that has power to explain the market abnormal returns in the announcement period is the FS. The evidence suggests that the market reaction to dividend change announcements is negatively associated with the firm size, which is consistent with previous studies, such as the ones of Haw and Kim (1991), Ghosh and Woolridge (1988) and Mitra and Owers (1995).

Analysing the influence of firm-specific factors on the probability of an inverse market reaction to dividend change announcements, we find evidence that dividend increases with high amplitude convey good news to the market, and that a high percentage of dividend negative changes decrease the likelihood that the market reacts positively to a dividend

\footnotetext{
${ }^{3}$ As this index is composed by five variables and we have already used some of them in the regression [ 2], we adopt the cash flow to assets' measure (CF) as a proxy for the financial constraints, which is also popular in the empirical tests done in this domain, computed as operating income before depreciation minus interest expense, income taxes and preferred stock dividends scaled by the total assets at the end of the year before the dividend announcement, as previously defined.

${ }^{4} \mathrm{We}$ could not have access to databases with this data. To obvious this problem, we assume that dividends follow a random walk, so, the average dividend change for a random sample of firms is, therefore, expected to be zero. Consequently, dividend changes were used as the proxy for the unexpected dividend changes.
} 
decrease announcement, which is consistent with the dividend signalling hypothesis (Dhillon and Johnson, 1994; Lee and Ryan, 2000, 2002; Hussin et al., 2010; Jiang and Stark, 2011). Furthermore, it is an indication that the magnitude of the dividend is directly associated with the signal dimension transmitted to the market (e.g. Asquith and Mullins, 1983).

In addition, the results suggest that the market reacts strongly to dividend decreases than to dividend increases, suggesting some asymmetry in the market reaction to dividend increases or decreases (e.g. Amihud and Li, 2002).

In what concerns the influence of firm-specific variables conditional on the direction of dividend announcements, we find for earnings change announcements conveying information beyond what is revealed by dividend change announcements, which is consistent with previous results (DeAngelo et al., 1992 and Abeyratna and Power, 2002).

Globally, we find some evidence for the dividend signalling hypothesis. 


\section{References:}

Abeyratna, G., \& Power, D. M. (2002). The Post-announcement Performance of Dividend-changing Companies: The Dividend-signalling Hypothesis Revisited. Accounting and Finance, 42, 131-151.

Aharony, J., \& Swary, I. (1980). Quarterly Dividend and Earnings Announcements and Stockholders Returns: An Empirical Analysis. The Journal of Finance, 35(1), 1-12.

Ahmad, H. \& Javid, A. (2009). Dynamics and Determinants of Dividend Policy in Pakistan: Evidence from Karachi Stock Exchange Non-financial Listed Firms. International Research Journal of Finance and Economics, 25, 148-171.

Ali, M. B., \& Chowdhury, T. A. (2010). Effect of Dividend on Stock Price in Emerging Stock Market: A Study on the Listed Private Commercial Banks in DSE. International Journal of Economics and Finance, 2(4), 52-64.

Amihud, Y. and Li, K. (2002). The Declining Information Content of Dividend Announcements and the Effect of Institutional Holdings. Working Paper, Stern School of Business, New York University.

Asamoah, G. N. (2010). The Impact of Dividend Announcement on Share Price Behaviour in Ghana. Journal of Business \& Economics Research, 8(4), 47-58.

Asquith, P., \& Mullins, D. W. (1983). The Impact of Initiating Dividend Payments on Shareholder Wealth. The Journal of Business, 56(1), 77-96.

Benartzi, S., Michaely, R., \& Thaler, R. (1997). Do Changes in Dividends Signal the Future or the Past?. The Journal of Finance, 52(3), 1007-1034.

Benesh, G. A., Keown, A. J., \& Pinkerton, J. M. (1984). An Examination of Market Reaction to Substantial Shifts in Dividend Policy. The Journal of Financial Research, 7(2), 131-142.

Bhattacharya, S. (1979). Imperfect Information, Dividend Policy, and 'The Bird in the Hand Fallacy'. Bell Journal of Economics, 10(1), 259-270.

Born, J. A., Moser, J. T., \& Officer, D. T. (1988). Changes in Dividend Policy and Subsequent Earnings. Journal of Portfolio Management, 14(4), 56-62.

Chen, G., Firth, M., \& Gao, N. (2002). The Information Content of Concurrently Announced Earnings, Cash Dividends, and Stock Dividends: An Investigation of the Chinese Stock Market. Journal of International Financial Management \& Accounting, 13(2), 101-124.

Conroy, R. M., Eades, K. M., \& Harris, R. S. (2000). A Test of the Relative Pricing Effects of Dividends and Earnings: Evidence from Simultaneous Announcements in Japan, The Journal of Finance, 55(3), 1199-1227. 
DeAngelo, H., DeAngelo, L., \& Skinner, D. J. (1992). Dividends and Losses. The Journal of Finance, 47(5), 1837-1863.

Dhillon, U. S., \& Johnson, H. (1994). The Effect of Dividend Changes on Stock and Bond Prices. The Journal of Finance, 49(1), 281-289.

Eddy, A., \& Seifert, B. (1988). Firm Size and Dividend Announcements. The Journal of Financial Research, 11(4), 295-302.

Fu, Y., and Morgan, H. (2008). "Dividend Policy and the Signalling Hypothesis: Is the Signalling Hypothesis Still Alive?", working paper available at http://www.sfu.ca/ hmorgan/sigallinghypothesis-HM,Yufen-spring2008.pdf.

Ghosh, C., \& Woolridge, J. R. (1988). An Analysis of Shareholder Reaction to Dividend Cuts and Omissions?. The Journal of Financial Research, 11(4), 281294.

Grullon, G. M. R., \& Swaminathan, B. (2002). Are Dividends Changes a Sign of Firm Maturity?. The Journal of Business, 75(3), 387-424.

Hausman, J. A. (1978). Specification Tests in Econometrics. Econometrica, 46(6), 1251-1271.

Haw, I., \& Kim, W. (1991). Firm Size and Dividend Announcement Effect. Journal of Accounting, Auditing and Finance, 6(3), 325-347.

Healy, J., Hathorn, J., \& Kirch, D. (1997). Earnings and the Differential Information Content of Initial Dividend Announcements. Accounting Enquiries, 6(2), 187-220.

Hussin, B. M., Ahmed, A. D., \& Ying, T. C. (2010). Semi-strong Form Efficiency: Market Reaction to Dividend and Earnings Announcements in Malaysian Stock Exchange, The IUP Journal of Applied Finance, 16(5), 36-60.

Jensen, M. (1986). Agency Costs of Free Cash Flow, Corporate Finance, and Takeover. American Economic Review, 76(2), 323-329.

Jiang, W. \& Stark, A. (2011). "Dividends, Accounting Information, and the Valuation of Loss-Making Firms in the UK", working paper, Available at SSRN: http://ssrn.com/abstract $=1734287$.

John, K., \& Williams, J. (1985). Dividends, Dilution, and Taxes: A Signalling Equilibrium. The Journal of Finance, 40(4), 1053-1070.

Kaplan, S. N., \& Zingales, L., (1997). Do Investment-cash Flow Sensitivities Provide Useful Measures of Financing Constraints?. The Quarterly Journal of Economics, 112(1), 169-215.

Lamont, O. A., Polk, C., \& Saá-Requejo, J. (2001). Financial Constraints and Stock Returns. The Review of Financial Studies, 14(2), 529-554. 
Lang, L. H. P., \& Litzenberger, R. H. (1989). Dividend Announcements: Cash Flow Signalling Versus Free Cash Flow Hypothesis. Journal of Financial Economics, 24(1), 181-191.

Lee, H. W., \& Ryan, P. A. (2002). Dividends and Earnings Revisited: Cause or Effect?. American Business Review, 20(1), 117-122.

Lee, H. W., \& Ryan, P. A. (2000). The Information Content of Dividend Initiations and Omissions: The Free Cash Flow and Dividend Signalling Hypotheses. The Journal of Research in Finance, 3(2), 196-277.

Lintner, J. (1956). Distribution of Incomes of Corporations among Dividends, Retained Earnings and Taxes. The American Economic Review, 46(2), 97-113.

Malkawi, H. (2008). Factors Influencing Corporate Dividend Decision: Evidence from Jordanian Panel Data. International Journal of Business, 13(2), 177-195.

Miller, M. H., \& Rock, K. (1985). Dividend Policy Under Asymmetric Information. The Journal of Finance, 40(4), 1031-1051.

Mitra, D. and Owers, J. (1995). Dividend Initiation Announcement Effects and the Firm's Information Environment. Journal of Business Finance and Accounting, 22(4), 551-573.

Pettit, R. (1976). The Impact of Dividends and Earnings Announcements: A Reconciliation. The Journal of Business, 49(1), 86-96.

Pettit, R. (1972). Dividend Announcements, Security Performance, and Capital Market Efficiency. The Journal of Finance, 27(5), 993-1007.

Urooj, S. F., \& Zafar, N. (2008). Share Price Reaction to Dividend Announcements. The Business Review, 10(1), 322-329.

White, H. (1980). A Heteroscedasticity-consistent Covariance Matrix Estimator and a Direct Test for Heteroscedasticity. Econometrica, 48(4), 149-170.

Yilmaz, M. K., \& Gulay, G. (2006). Dividend Policies and Price-Volume Reactions to Cash Dividends on the Stock Market: Evidence from the Istanbul Stock Exchange. Emerging Markets, Finance \& Trade, 42(4), 19-49.

Yilmaz, A. A., \& Selcuk, E. A. (2010). Information Content of Dividends: Evidence from Istanbul Stock Exchange. International Business Research, 3(3), 126-132. 


\section{Appendix}

\section{Table 1 - Regression of BHAR on firm specific variables and}

\section{correlation matrix}

This table reports the estimation of a regression relating cumulative abnormal return (BHAR) in the announcement period to firm specific variables and the correlations between the independent variables. Panel A presents the Pearson correlations between independent variables. $\mathrm{FS}_{\mathrm{i}}$ is the firm size (natural $\log$ of the market value of common equity at the end of the year before the dividend change year); $\mathrm{PCD}_{\mathrm{i}}$ is the percentage change of dividends (the annual change in dividends divided by the share price in the announcement day); $\mathrm{EG}_{\mathrm{i}}$ is the earnings growth rate (the average earnings growth rate based on the year prior to the dividend change year); $M B_{i}$ is the market to book ratio (market price per share at the dividend change announcement date divided by the book value per share at the end of the year before the dividend change year); $\mathrm{PER}_{\mathrm{i}}$ is the price earnings ratio (the price per share at the announcement date divided by the earnings per share at the end of the year before the dividend change year); $\mathrm{DE}_{\mathrm{i}}$ is the debt to equity ratio (the book value of total debt divided by the total book value of equity at the end of the year prior to the dividend change announcement). Panel B presents the regression results for the best model (OLS, FEM or REM). It reports the F test, a test for the equality of sets of coefficients, and the Hausman (1978) test, a test with $\mathrm{H}_{0}$ : random effects are consistent and efficient, versus $\mathrm{H}_{1}$ : random effects are inconsistent, in order to choose the most appropriate model for each particular sample. The numbers in parentheses are the t-statistics corrected for heteroscedasticity using the White (1980) method.

\begin{tabular}{|c|c|c|c|c|c|c|}
\hline \multicolumn{7}{|c|}{ Panel A: Pearson correlations between independent variables } \\
\hline & FS & PCD & EG & MB & PER & DE \\
\hline Firm Size (FS) & 1.000 & - & 0.012 & -0.005 & $0.030^{*}$ & $0.084^{*}$ \\
\hline$\%$ Change Div. & & 1.000 & 0.017 & 0.007 & $0.024 *$ & -0.015 \\
\hline Earnings Growth & & & 1.000 & -0.010 & $0.028^{*}$ & -0.010 \\
\hline Market to Book & & & & 1.000 & $0.064 * *$ & $0.344^{*}$ \\
\hline PER & & & & & 1.000 & - \\
\hline
\end{tabular}


Debt/Equity (DE)

1.000

Panel B:

$\left|B H A R_{i, 1 t o+1}\right|=\alpha+\beta_{1} F S_{i}+\beta_{2}\left|P C D_{i}\right|+\beta_{3}\left|E G_{i}\right|+\beta_{4} M B_{i}+\beta_{5} P E R_{i}+\beta_{6} D E_{i}+\theta c+\varepsilon_{i, t}$

\begin{tabular}{|c|c|c|c|c|}
\hline Coefficient & $\begin{array}{c}\text { Expected } \\
\text { Signal } \\
\end{array}$ & FEM & $\mathbf{t}$ & \\
\hline Constant & & 0.063 & $(7.492)$ & $* * *$ \\
\hline Firm Size & - & -0.003 & $(-$ & $* * *$ \\
\hline$\%$ Change of Divid. & + & -0.001 & $(-$ & \\
\hline Earnings Growth & + & -0.001 & $(-$ & \\
\hline Market to Book ratio & + & -0.001 & $(-$ & \\
\hline Price/Earnings ratio & $+/-$ & 0.000 & $(0.358)$ & \\
\hline Debt to Equity ratio & + & 0.001 & $(0.293)$ & \\
\hline Country effects & yes & & & \\
\hline $\mathrm{N}$ & & 4,442 & & \\
\hline Adjusted $\mathrm{R}^{2}$ & & 0.216 & & \\
\hline Test F & & 0.934 & & \\
\hline Hausman Test & & 10.646 & & \\
\hline
\end{tabular}

*** Significantly different from zero at the $1 \%$ level

** Significantly different from zero at the $5 \%$ level

* $\quad$ Significantly different from zero at the $10 \%$ level 


\section{Table 2 - Logistic regression of the negative (positive) reaction to}

\section{dividend increase (decrease) announcements and firm specific variables}

This table reports the estimation of a logistic regression relating the negative reaction to dividend increase announcements (Panel A) and the positive reaction to dividend decrease announcements (Panel $\mathrm{B}$ ) and firm specific variables. BHARI $\mathrm{i}_{\mathrm{i}, 1}$ to +1 is a dummy variable that takes value 1 if $B H A R_{i,-1 t+1}$ is negative and 0 otherwise; $\mathrm{BHARD}_{\mathrm{i},-1 \text { to }+1}$ is a dummy variable that takes value 1 if $\mathrm{BHAR}_{\mathrm{i},-1 \text { to }+1}$ is positive and 0 otherwise; $\mathrm{FS}_{\mathrm{i}}$ is the firm size, computed as the natural log of market value of common equity at the end of the year before the dividend change year; $\mathrm{LPCD}_{\mathrm{i}}$ is the natural logarithm of annual change in dividends divided by the share price in the announcement day +1 ;EG $_{\mathrm{i}}$ is the natural logarithm of average earnings growth rate based on the year prior to the dividend change year $+1 \mathrm{LMB}_{\mathrm{i}}$ is natural logarithm of market price per share at the dividend change announcement date by the book value per share at the end of the year before the dividend change year $+1 ; \mathrm{LDE}_{\mathrm{i}}$ is the natural logarithm of book value of total debt divided by the total book value of equity at the end of the year prior to the dividend change announcement +1 . We report the coefficient values and the $z$-values (in parentheses).

\section{Panel A: Dividend Increases}

BHARI $_{i, 1 \text { to }+1}=\alpha+\beta_{1} F S_{i}+\beta_{2} L P C D_{i}+\beta_{3} L E G_{i}+\beta_{4} L M B_{i}+\beta_{5} L P E R_{i}+\beta_{6} L D E_{i}+\theta c+\varepsilon_{t}$

\begin{tabular}{|c|c|c|c|c|}
\hline & & Coefficient & $z$-value & \\
\hline Constant & & -0.6346 & $(-2.114)$ & $* *$ \\
\hline Firm Size & & -0.0173 & $(-0.923)$ & \\
\hline Log $\%$ Change of Dividends & & -0.0546 & $(-1.596)$ & $*$ \\
\hline Log Earnings Growth & & -0.0111 & $(-0.402)$ & \\
\hline Log Market to Book ratio & & 0.0813 & $(1.458)$ & $*$ \\
\hline Log Price/Earnings ratio & & -0.0081 & $(-0.139)$ & \\
\hline Log Debt to Equity ratio & & -0.0542 & $(-1.261)$ & \\
\hline Country effects & yes & & & \\
\hline $\begin{array}{r}\mathrm{N} \\
\mathrm{R}^{2}\end{array}$ & & $\begin{array}{l}2,927 \\
0.002\end{array}$ & & \\
\hline
\end{tabular}

Panel B: Dividend Decreases

$B H A R D_{l,-1 \mathrm{to}+1}=a \dashv \beta_{1} F S_{i} \dashv \beta_{2} \mathrm{LPCD}_{\mathrm{i}} \dashv \beta_{3} \mathrm{LEG}_{\mathrm{i}} \dashv \beta_{4} L M B_{i} \dashv \beta_{5} L P E R_{i} \dashv \beta_{6} L D E_{i} \dashv \varepsilon_{t}$

\begin{tabular}{|c|c|c|c|}
\hline & Coefficient & $z$-value & \\
\hline Constant & -1.3108 & $(-2.387)$ & $* * *$ \\
\hline Firm Size & 0.0049 & $(0.118)$ & \\
\hline Log $\%$ Change of Dividends & -0.1198 & $(-2.074)$ & $* *$ \\
\hline Log Earnings Growth & -0.0654 & $(-1.148)$ & \\
\hline
\end{tabular}




\begin{tabular}{|c|c|c|c|}
\hline Log Market to Book ratio & & -0.4126 & $(-3.198) * * *$ \\
\hline Log Price/Earnings ratio & & 0.0375 & $(0.399)$ \\
\hline Log Debt to Equity ratio & & 0.0252 & $(0.268)$ \\
\hline Country effects & yes & & \\
\hline $\begin{array}{l}\mathrm{N} \\
\mathrm{R}^{2}\end{array}$ & & $\begin{array}{r}686 \\
0.019\end{array}$ & \\
\hline
\end{tabular}

*** Significantly different from zero at the $1 \%$ level

** Significantly different from zero at the $5 \%$ level

* $\quad$ Significantly different from zero at the $10 \%$ level

\section{Table 3 - Regression of BHAR on firm specific variables with dummies}

This table reports the estimation of a regression relating the BHAR in the event period to firm specific factors using dummy variables to identify dividend increase and decrease events. $\mathrm{FS}_{\mathrm{i}}$ is the firm size, computed as the natural log of the market value of common equity at the end of the year before the dividend change year; $\mathrm{PCD}_{\mathrm{i}}$ is the percentage change of dividends, computed as the annual change in dividends divided by the share price in the announcement day; $\mathrm{EG}_{\mathrm{i}}$ is the earnings growth rate, computed as the average earnings growth rate based on the year prior to the dividend change year; $\mathrm{MB}_{\mathrm{i}}$ is the market to book ratio, calculated by dividing the market price per share at the dividend change announcement date by the book value per share at the end of the year before the dividend change year; $\mathrm{DE}_{\mathrm{i}}$ is the debt to equity ratio, calculated as the book value of total debt divided by the total book value of equity at the end of the year prior to the dividend change announcement; $\Phi$ is the vector of coefficients for the dummy variables relating dividend and earnings changes, set equal to 1 respectively, if both dividend and earnings increases, dividend increases and earnings decreases, dividend decreases and earnings increases, both dividend and earnings decreases, and 0 otherwise. The table presents the regression results for the best model (OLS, FEM or REM). It reports the $\mathrm{F}$ test, a test for the equality of sets of coefficients, and the Hausman (1978) test, a test with $\mathrm{H}_{0}$ : random effects are consistent and efficient, versus $\mathrm{H}_{1}$ : random effects are inconsistent, in order to choose the most appropriate model for each particular sample. The numbers in parentheses are the t-statistics corrected for heteroscedasticity using the White (1980) method. 


\begin{tabular}{|c|c|c|c|}
\hline \multicolumn{4}{|c|}{$\begin{aligned}\left|B H A R_{i, 1 \text { to }+1}\right| & =\alpha+\beta_{1} \Phi \times F S_{i}+\beta_{2} \Phi x\left|P C D_{i}\right|+\beta_{3} \Phi x\left|E G_{i}\right|+ \\
+ & \beta_{4} \Phi \times M B_{i}+\beta_{5} \Phi \times P E R_{i}+\beta_{6} \Phi \times D E_{i}+\theta c+\varepsilon_{i, t}\end{aligned}$} \\
\hline Coefficient & FEM & $\mathbf{t}$ & \\
\hline Constant & 0.0279 & $(4.747)$ & $* * *$ \\
\hline DIEI $x$ FS & -0.0008 & $(-3.151)$ & $* * *$ \\
\hline DIED x FS & -0.0007 & $(-2.144)$ & $* *$ \\
\hline DDEI $x$ FS & -0.0014 & $(-2.913)$ & $* * *$ \\
\hline DDED $x$ FS & -0.0015 & $(-2.958)$ & $* * *$ \\
\hline DIEI x PCD & 0.0053 & $(0.403)$ & \\
\hline DIED $\times$ PCD & 0.0152 & $(0.709)$ & \\
\hline DDEI $x$ PCD & 0.0122 & (1.132) & \\
\hline DDED $\times$ PCD & -0.0034 & $(-1.029)$ & \\
\hline DIEI x EG & 0.0001 & $(0.010)$ & \\
\hline DIED x EG & 0.0005 & $(0.334)$ & \\
\hline DDEI $x$ EG & -0.0008 & $(-0.508)$ & \\
\hline DDED x EG & -0.0012 & $(-0.751)$ & \\
\hline DIEI $x$ MB & -0.0002 & $(-0.327)$ & \\
\hline DIED x MB & -0.0001 & $(-0.200)$ & \\
\hline DDEI x MB & 0.0002 & $(0.473)$ & \\
\hline DDED x MB & -0.0002 & $(-0.032)$ & \\
\hline DIEI x PER & 0.0008 & $(0.588)$ & \\
\hline DIED x PER & 0.0005 & $(0.028)$ & \\
\hline DDEI x PER & 0.0007 & (2.387) & $* *$ \\
\hline DDED $x$ PER & -0.0004 & $(-1.648)$ & * \\
\hline DIEI $x$ DE & -0.0001 & $(-0.457)$ & \\
\hline DIED x DE & -0.0008 & $(-0.172)$ & \\
\hline DDEI $x$ DE & 0.0001 & $(0.155)$ & \\
\hline DDED x DE & -0.0003 & $(-0.437)$ & \\
\hline Country effects & & & \\
\hline $\mathrm{N}$ & 4.442 & & \\
\hline Adjusted $\mathrm{R}^{2}$ & 0.212 & & \\
\hline Test F & 0.937 & & \\
\hline Hausman Test & 12.062 & & \\
\hline
\end{tabular}

*** Significantly different from zero at the $1 \%$ level

** Significantly different from zero at the $5 \%$ level

* $\quad$ Significantly different from zero at the $10 \%$ level 


\section{Table 4 - Selected specific variables for the sub-samples of events, according to the relationship between dividend change announcements and the BHAR}

This table reports the mean values of selected specific factors for the different groups classified according to the relation between dividend change announcements and the subsequent market reaction. $\mathrm{FS}_{\mathrm{i}}$ is the firm size for share $\mathrm{i}$, computed as the natural $\log$ of market value of common equity at the end of the year before the dividend change year; $\mathrm{PCD}_{\mathrm{i}}$ is the percentage change of dividends for share $\mathrm{i}$, computed as the annual change in dividends divided by the share price in the announcement day; $E_{i}$ is the earnings growth rate for share $i$, computed as the average earnings growth rate based on the year prior to the dividend change year; $\mathrm{MB}_{\mathrm{i}}$ is the market to book ratio for share $\mathrm{i}$, calculated by dividing the market price per share at the dividend change announcement date by the book value per share at the end of the year before the dividend change year; $\mathrm{PER}_{\mathrm{i}}$ is the price earnings ratio for share $i$, computed as the price per share at the announcement date divided by the earnings per share at the end of the year before the dividend change year; $\mathrm{DE}_{\mathrm{i}}$ is the debt/equity ratio for share $\mathrm{i}$, calculated as the book value of total debt divided by the total book value of equity at the end of the year prior to the dividend change announcement; PRDI identifies the events with a positive reaction to dividend increases; NRDD identifies the events with a negative reaction to dividend decreases; NRDI identifies the events with a negative reaction to dividend increases; PRDD identifies the events with a positive reaction to dividend decreases. In addition, the table also presents the value of the $t$-statistic to test for the differences between the means of two groups.

\begin{tabular}{|c|c|c|c|c|c|c|}
\hline \multicolumn{7}{|c|}{ Relation between dividend changes and BHAR } \\
\hline Variables & $\begin{array}{l}\text { PRDI } \\
\text { (I) }\end{array}$ & $\begin{array}{l}\text { NRDI } \\
\text { (II) }\end{array}$ & $\begin{array}{l}\text { t - statistic } \\
\text { (I)-(II) }\end{array}$ & $\begin{array}{l}\text { NRDD } \\
\text { (III) }\end{array}$ & $\begin{array}{c}\text { PRDD } \\
\text { (IV) }\end{array}$ & $\begin{array}{l}\text { t - statistic } \\
\text { (III)-(IV) }\end{array}$ \\
\hline Firm size & 12.964 & 12.960 & 0.004 & 12.695 & 12.677 & 0.018 \\
\hline $\begin{array}{l}\% \text { Change in } \\
\text { dividends }\end{array}$ & 0.008 & 0.011 & -0.003 & -0.042 & -0.022 & -0.020 \\
\hline Earnings growth & 0.225 & 0.302 & -0.077 & -0.101 & 0.135 & -0.236 \\
\hline Market to book ratio & 2.528 & 2.912 & -0.384 & 1.505 & 1.611 & -0.106 \\
\hline Price/earnings ratio & 16.759 & 16.885 & -0.126 & 14.234 & 12.536 & $1.698 *$ \\
\hline Debt/Equity ratio & 1.619 & 1.731 & -0.112 & 2.068 & 1.597 & 0.471 \\
\hline
\end{tabular}

*** Significantly different from zero at the $1 \%$ level

* $\quad$ Significantly different from zero at the $10 \%$ level 
